$\begin{gathered}\text { Науковий вісник НЛтУ України } \\ \text { Scientific Bulletin of UNFU } \\ \text { http://nv.nltu.edu.ua }\end{gathered}$
$\begin{gathered}\text { https://doi.org/10.15421/40290401 } \\ \text { Article received 19.03.2019 p. } \\ \text { Article accepted 25.04.2019 p. } \\ \text { Удк 330.342:303.725.2 1994-7836 (print) }\end{gathered}$

Я. В. Кульчицький' , Б. В. Кульчицький², Л. В. Рібун

${ }^{1}$ Національний лісотехнічний університет Украӥни, м. Львів, Украӥна

${ }^{2}$ Львівський національний університет ім. Івана Франка, м. Львів, Украӥна

\title{
ЕКОЛОГІЧНА ПАРАДИГМА ЕКОНОМІЧНОЇ КОМПАРАТИВІСТИКИ ХХІ СТОЛІТТЯ
}

Актуальність проблеми взаємин людини і довкілля зумовило утвердження в економічній теорії екологічної парадигми, яка передбачає розгляд усіх економічних і соціальних процесів крізь призму збереження довкілля, умов існування і розвитку людської особистості. Наголошено, що сучасні підручники з економічної теорії недостатньо враховують екологічний імператив, оскільки необхідно досліджувати поведінку людей у процесі виробництва, розподілу і споживання матеріальних благ та послуг не просто в умовах обмежених ресурсів, а уже в нових умовах - посилення екологічної кризи глобального, регіонального і локального характеру. Розкрито інституційні засади екологізації сучасних економічних систем із позицій постіндустріальної парадигми та економічної компаративістики в умовах посилення глобалізації. Виявлено зміст екологічної парадигми економічної теорії та обгрунтовано потребу виокремлення соціально-екологічних відносин у системі економічних відносин суспільства. Проаналізовано концепцію сталого розвитку та особливості еколого-економічних інструментів у розвинутих країнах. Підкреслено важливість формування сучасної екологічної культури у процесі трансформації економічних систем, коли в ії основі мають бути орієнтованість на екологічну доцільність і безпеку, відсутність протиставлення людини і природи. Запропоновано авторське трактування процесу екологізації сучасних економічних систем в умовах посилення глобалізації, переходу людства до суспільства знань та "зеленої економіки". Під екологізацією економічних систем пропонуємо розуміти посилення екологічної спрямованості економічних систем у процесі їх трансформації, що виявляється у становленні сучасної економічної та екологічної свідомості та культури, екологічної відповідальності, в утвердженні сучасних екологічних цінностей, формуванні відповідної нормативно-правової, інституційної бази, спрямованої на суспільний контроль за системою зв'язків "людина - економіка - екологія", застосуванні санкцій і стимулів щодо впливу економічної системи на стан екологічної рівноваги в умовах обмеженості природних ресурсів і посилення екологічної кризи глобального, регіонального і локального характеру. Екологізація економічних систем є об'єктивним процесом їх трансформації, домінантою трансформації на зламі тисячоліть, що утверджує усвідомлення екологічних проблем як глобальних. Екологізація економічних систем розглядається сьогодні як дуже важливий, навіть визначальний критерій порівняльного аналізу національних систем чи наднаціональних системних утворень. Обгрунтовано екологічну парадигму економічної компаративістики XXI ст.

Ключові слова: економічні системи; екологізація економічних систем; сталий розвиток; екологічна парадигма економічної теорії та економічної компаративістики XXI ст.

Вступ. Дослідження теоретико-методологічних засад розвитку сучасних економічних систем об'єктивно передбачає виявлення пріоритетних домінант їх трансформації, якими у XXI ст. є, на наш погляд, екологізація та глобалізація. Саме ці процеси здійснюють нині вирішальний вплив на функціонування і трансформацію існуючих чи становлення нових економічних систем. Будучи тісно взаємопов'язаними між собою, вони зумовлюють ключові параметри економічних систем, їх елементну структуру, визначають найважливіші функції. I хоча актуальність проблеми екологізації економіки не підлягає сумніву, проте більшість наявних наукових досліджень мають або виключно економічний, прагматичний ухил, або природоохоронну спрямованість у чистому вигляді. Звідси випливає потреба комплексного підходу до цієї складної й важливої теоретичної і практичної проблеми на основі діалогу еконо- мічної та інших наук.

Метою дослідження є розроблення теоретико-методологічних засад дослідження і з'ясування змісту екологізації сучасних економічних систем у контексті теорії порівняльних систем чи економічної компаративістики XXI ст., що має дуже важливе значення для методології економічної теорії, а також практики державного регулювання взаємодії економічної та екологічної систем та забезпечення сталого розвитку як розвинених, так i транзитивних, перехідних економічних систем в умовах посилення глобалізації.

Доводимо потребу теоретичного виокремлення соціально-екологічних відносин у системі економічних відносин суспільства та відображення цього у поняттєвому апараті економічної теорії. Розкриваємо зміст і вважаємо за доцільне запровадити до наукового обігу в економічній теорії поняття "екологізація економічних сис-

Інформація про авторів:

Кульчицький Ярослав Володимирович, д-р екон. наук, професор, кафедра економічної теорії. Email: kulchytskyj.br@ukr.net Кульчицький Богдан Володимирович, д-р екон. наук, професор, кафедра економічної теорії. Email: kulchytskyj.br@ukr.net Рібун Любомир Володимирович, канд. екон. наук, доцент, завідувач кафедри економічної теорії. Email: kulchytskyj.br@ukr.net Цитування за ДСтУ: Кульчицький Я. В., Кульчицький Б. В., Рібун Л. В. Екологічна парадигма економічної компаративістики XXI століття. Науковий вісник НЛтУ України. 2019, т. 29, № 4. С. 7-10.

Citation APA: Kul'chyts'kyj, Ya. V., Kul'chyts'kyj, B. V., \& Ribun, L. V. (2019). The ecological paradigm of the comparative analysis of economic systems of the 21 century. Scientific Bulletin of UNFU, 29(4), 7-10. https://doi.org/10.15421/40290401 
тем". Окрім цього, пропонуємо низку екологічних показників-критеріїв порівняльного аналізу сучасних економічних систем, що в сукупності й становить зміст екологічної парадигми економічної компаративістики XXI ст.

Методами дослідження є насамперед діалектичний, історичний, логічний, аналіз і синтез, системний, синергетичний, порівняльного аналізу, сценарного підходу, міждисциплінарний та ін.

Ступінь розроблення проблеми та огляд літератури. Варто підкреслити, що, незважаючи на значну актуальність проблеми парадигмальних змін в економічній теорії та економічній компаративістиці XXI ст. під впливом посилення екологізації економічних систем як пріоритету їх трансформації в умовах епохального переходу людства до інформаційного, "знаннєвого" суспільства та "зеленої економіки", науковці мають часто досить різне, відмінне бачення і тлумачення цієї проблеми. Тому ми намагатимемось виявити основні підходи до ії вирішення та обгрунтувати власну наукову концепцію (Kulchytskyi, Kulchytskyi, \& Dzhyhora, 2016; Kulchytskyi et al., 2017a).

Дослідження економічної та екологічної діяльності на початку XXI ст. в умовах значного посилення об'єктивних процесів екологізації сучасних економічних систем зумовлює, на наше глибоке переконання, потребу перегляду багатьох застарілих методологічних положень економічної теорії (Kulchytskyi, \& Kulchytskyi, 2015, p. 259; Kulchytskyi, 2017, p. 68; Kulchytskyi, Kulchytskyi, \& Malinovska, 2018). Практичними причинами таких тенденцій стали актуальні проблеми взаємин людини і довкілля (Kulchytskyi, \& Kulchytskyi, 2015, p. 259; Kulchytskyi, Kulchytskyi, \& Malinovska, 2018). Внаслідок цих складних тенденцій в економічній теорії та економічній компаративістиці почала міцно утверджуватися екологічна парадигма, яка передбачає розгляд усіх економічних і соціальних процесів крізь призму збереження довкілля, умов існування і розвитку людської особистості (Kulchytskyi, \& Kulchytskyi, 2015, pp. 258 259; Kulchytskyi, 2011, pp. 240-241; Kulchytskyi, 2005, 2003, 2008; Kulchytskyi et al., 2017b; Kulchytskyi, 2017, pp. 68-69; Kulchytskyi, Kulchytskyi, \& Malinovska, 2018). Як обгрунтовано зазначають у цьому контексті зарубіжні дослідники, екологічна парадигма економічної теорії починається насамперед з критики можливостей традиційного неокласичного оптимізаційного аналізу щодо вирішення проблеми деградації і охорони довкілля, а також забезпечення відповідної його якості та доступності природних засобів для майбутніх поколінь (Fiedor et al., 2012, p. 22).

На думку Ю. Туниці, між традиційною ринковою економікою та екологічними вимогами існують глибокі суперечності. Тому головною проблемою сучасної економічної науки повинно бути формування нової екологічної економіки: "Наука повинна зробити все можливе для адаптації ринкової моделі економіки до вимог екологічної економіки, понад це, в реальному житті повинна відбутися трансформація ринкової економіки в екологічну" (Tunytsia, 2006, p. 21). Учений слушно вважає, що економічна наука на початку третього тисячоліття мусить змінити або принаймні істотно уточнити свою парадигму, оскільки "предмет класичної і неокласичної економіки стає ширшим і складнішим у зв'язку з розширенням поняття третього чинника виробництва "при- родні ресурси" до поняття "природне довкілля" (environment)" (Tunytsia, 2006, pp. 26-27).

Сучасні зарубіжні підручники з економічної теорії недостатньо враховують екологічний імператив, оскільки необхідно досліджувати поведінку людей у процесі виробництва, розподілу і споживання матеріальних благ та послуг не просто в умовах обмежених ресурсів, а уже в нових умовах -посилення екологічної кризи глобального, регіонального і локального характеру. На думку Ю. Туниці, йдеться про істотні зміни предмету економіки або ж формування, поруч з класичною і неокласичною економічною теорією, нової еколого-еко-

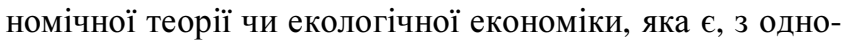
го боку, продуктом розвитку економічної думки в історичній ретроспективі та спирається на досягнення новітньої економічної теорії, а 3 іншого - результатом спостережень та аналізу розвитку сучасного світу, його природи і суспільства, результатом аналізу цілком нових екологічних проблем (Tunytsia, 2006, pp. 26-29). Загалом учений наголошує: "3 одного боку, екологічна економіка є складовою частиною економічної теорії, 3 іншого - вона вимагає докорінної зміни сутності й змісту економічних наук щодо відображення ними екологічного імперативу..." (Tunytsia, 2006, p. 83).

Ми повністю поділяємо точку зору Ю. Туниці, який виводить екологічну економіку з економічної теорії i вважає іiї складовою останньої. Справді, яким би не був жвавим діалог економічної та інших наук, але оновлена й збагачена сучасними концептами та постіндустріальною парадигмою економічна теорія та економічна компаративістика $є$ саме тим методологічним фундаментом, річищем, у руслі якого виокремлюється екологічна економіка як відображення об'єктивного процесу утвердження екологічного імперативу саме в економічній теорії. Підсумовуючи роздуми про екологічний імператив у новітній економічній теорії, учений аргументовано наголошує, що "...повинна відбуватися екологізація економічної теорії та інших економічних дисциплін i, водночас, економізація екології та інших природничих дисциплін" (Tunytsia, 2006, p. 84).

Туниця Ю. переконливо обгрунтовує і висуває ідею створення Екологічної Конституції Землі (ЕКЗ) та необхідності якомога швидшого іiї опрацювання і схвалення (Tunytsia, 2006, p. 203). Як слушно вважає дослідник, ЕКЗ повинна мати статус Основного Закону виживання цивілізації та сталого розвитку, який, не загрожуючи суверенітету жодної країни, іï політичному ладу, віросповіданню громадян, національним інтересам, водночас забезпечував би кожній державі, зокрема і світовому співтовариству загалом, екологічну та економічну безпеку, а окремій людині - нормальні для ії життя природні умови як нині, так і в майбутньому (Tunytsia, 2006, pр. 195-196).

У розвинених економічних системах способами реалізації еколого-економічних інструментів $є$ їх відповідні форми, серед яких найбільшого поширення набули такі: 1) податкові інструменти; 2) мита; 3) платежі; 4) штрафи; 5) субсидії; 6) дотації; 7) гранти; 8) кредитні інструменти; 9) виплати; 10) пришвидшена амортизація; 11) цінові інструменти. Так, зокрема у промислово розвинених країнах світу спостерігаємо тенденцію до зростання ролі екологічних податків та їх стимулювального впливу на розвиток економіки. Частка екологічних податків загалом від оподаткування юридичних і фізич- 
них осіб становить: у США - 3,2 \%, Данії- 3,4 \%, Австрії - 4,4 \%, Канаді - 4,5 \%, Швейцарії - 4,7 \%, Німеччині - 4,9 \%, Франції - 5,4 \%, Нідерландах - 5,5\%, Греції- 6,1 \%, Новій Зеландії- 6,1\%, Японії- 6,5\%, Фінляндії - 7,3\%, Іспанії - 7,5\%, Великобританії 8,2 \%, Італії - 9,0 \%, Норвегії - 10,8 \%, Португалії 11,5\%, Ірландіï - 11,9 \% (Melnyk, 2006, p. 115).

Об'єктивні зміни, що відбуваються нині в розвинених економічних системах, повинні, на наше глибоке переконання, знайти відображення у теоретичному виокремленні соціально-екологічних відносин у системі економічних відносин суспільства. При цьому вважаємо, що під соціально-екологічними відносинами потрібно розуміти відносини, які об'єктивно складаються між суб'єктами економічної системи суспільства, еколого-економічної діяльності у процесі свідомого перетворення природного світу на основі відповідної економічної та екологічної культури. Такий підхід дав би змогу не тільки зосередити увагу вчених-теоретиків на розкритті змісту й місця соціально-екологічних відносин у поняттєвому апараті економічної теорії та економічної компаративістики, але й надати потужного стимулу для всебічного вивчення особливостей функціонування цих відносин у сучасних розвинених економічних системах 3 метою їх максимального врахування в економічній та екологічній політиці країн 3 перехідними економічними системами у процесі їх трансформації в умовах посилення екологізації та глобалізації (Kulchytskyi, \& Kulchytskyi, 2015, p. 266; Kulchytskyi, 2011, pp. 240-318; Kulchytskyi, 2005, pp. 105-121; Kulchytskyi, 2003; Kulchytskyi, \& Kulchytskyi, 2007, pp. 54-58; Kulchytskyi, 2008; Kulchytskyi, Kulchytskyi, \& Malinovska, 2018).

Висновки. Стверджуючи нагальність засвоєння суспільною свідомістю екоцентричної системи цінностей та настанов, ідеї "зеленої економіки", ми дійшли висновку про глибоке розуміння важливості екологічної свідомості та культури у процесі становлення і трансформації економічних систем, у процесі вдосконалення та розвитку методології економічної теорії та економічної компаративістики XXI ст. (Kulchytskyi, \& Kulchytskyi, 2015, pp. 275-280; Kulchytskyi, 2005, 2003; Kulchytskyi, \& Kulchytskyi, 2007, pp. 64-65; Kulchytskyi, 2008; Kulchytskyi, Kulchytskyi, \& Malinovska, 2018). У підгрунтя формування сучасної екологічної культури мають бути покладені насамперед орієнтованість на екологічну доцільність і безпеку, відсутність протиставлення людини і природи, сприйняття природних об'єктів як повноправних партнерів у взаємодії з людиною (Kulchytskyi, \& Kulchytskyi, 2015, pp. 278-279; Kulchytskyi, Kulchytskyi, \& Malinovska, 2018).

Подальший розвиток економічної теорії та економічної компаративістики повинен враховувати певну відособленість, автономність наукових досліджень власне екологічних проблем, з одного боку, та досліджень сучасних економічних систем - 3 іншого боку, а також діалектичну єдність, нерозривність і глибинну взаємозалежність, взаємозумовленість довкілля, природи, екосистеми та економічної системи. У цьому контексті вважаємо за доцільне запровадити до наукового обігу в економічній теорії та економічній компаративістиці XXI ст. поняття "екологізація економічних систем". Під екологізацією економічних систем пропонуємо розуміти посилення екологічної спрямованості економічних систем у процесі їх трансформації, що виявляється у становленні сучасної економічної та екологічної свідомості та культури, екологічної відповідальності, в утвердженні сучасних екологічних цінностей, формуванні відповідної нормативно-правової, інституційної бази, спрямованої на суспільний контроль за системою зв'язків "людина - економіка - екологія", застосуванні санкцій і стимулів щодо впливу економічної системи на стан екологічної рівноваги в умовах обмеженості природних ресурсів та посилення екологічної кризи глобального, регіонального і локального характеру. Екологізація економічних систем є об'єктивним процесом їх трансформації, домінантою трансформації на зламі тисячоліть, що утверджує усвідомлення екологічних проблем як глобальних. Екологізація економічних систем розглядається сьогодні як надзвичайно важливий, навіть визначальний критерій порівняльного аналізу національних систем чи наднаціональних системних утворень.

Ми вважаємо, що порівняльний аналіз сучасних економічних систем в умовах посилення їх екологізації, інтелектуалізації та глобалізації має грунтуватися на новітніх філософсько-методологічних засадах, які повинні включати цивілізаційний, гуманістичний підхід, спиратися на теорію інформаційного (постіндустріального) суспільства як глобальну методологічну парадигму, якісно новий тип економічної та екологічної свідомості й культури, поліфонічне бачення економіки, довкілля, духовної, соціально-політичної, правової та інших сфер як єдиного суспільного організму.

Відповідно пропонуємо низку екологічних показників-критеріїв порівняльного аналізу сучасних економічних систем, що в сукупності й розкриває зміст екологічної парадигми економічної компаративістики XXI ст. На наше переконання, будувати новітню концепцію економічної компаративістики XXI ст. необхідно, спираючись не тільки на традиційні показники-критерії (панівні форми власності на основні засоби і результати виробництва; способи досягнення макроекономічної рівноваги або співвідношення плану і ринку; особливості розподілу і перерозподілу доходів), а й на такі, як: 1) панівні суспільні цінності (економічні, екологічні, культурні, правові та ін.) та відповідні їм інституції; 2) рівень екологізації економічної системи; 3) ступінь екологічної безпеки / небезпеки; 4) ступінь забезпечення сталого розвитку системи; 5) суспільний контроль за системою зв'язків "людина - економіка - екологія"; 6) питома вага у забрудненні планети; 7) участь у вирішенні планетарних екологічних проблем та ін.

Ці показники-критерії порівняльного аналізу сучасних економічних систем можна конкретизувати в низці таких екологічних показників-критеріїв, як: 1) частка природоохоронних витрат у ВВП; 2) ступінь чистоти повітряного і водного басейнів; 3) величина радіоактивного фону; 4) ступінь екологічності продуктів харчування; 5) частка лісонасаджень до загальної площі; 6) частка електроенергії, яка виробляється за допомогою екологічно чистих технологій (за допомогою енергії сонця, вітру, води); 7) ступінь утилізації екологічно шкідливих відходів та ін.

\section{Перелік використаних джерел}

Kulchytskyi, Ya. V., \& Kulchytskyi, B. V. (2015). Filosofiia ekonomichnykh system (rozvytok metodolohii yikh porivnialnoho analizu 
$v$ umovakh ekolohizatsii, intelektualizatsii ta hlobalizatsii). Lviv: Liha-Pres, 710 p. [In Ukrainian].

Kulchytskyi, Ya. V. (2011). Suchasni ekonomichni systemy v umovakh ekolohizatsii ta hlobalizatsii (teoretyko-metodolohichni zasady porivniannia). Lviv: Liha-Pres, 687 p. [In Ukrainian].

Kulchytskyi, Ya. V. (2005). Problemy formuvannia sotsialno-ekolohichnykh suspilnykh vidnosyn u konteksti transformatsii suchasnykh ekoloho-ekonomichnykh system. Lviv: Kamula, 144 p. [In Ukrainian].

Kulchytskyi, Ya. V. (2003). Ekoloho-ekonomichni systemy (problemy teorii i metodolohii doslidzhennia). Lviv: UkrDLTU, 64 p. [In Ukrainian].

Kulchytskyi, Ya. V., \& Kulchytskyi, B. V. (2007). Porivniannia ekonomichnykh system (problemy metodolohii). Lviv: Vyd. tsentr LNU imeni Ivana Franka, 318 p. [In Ukrainian].

Kulchytskyi, Ya. V. (2008). Ekolohizatsiia ekonomichnykh system u konteksti postindustrialnoho paradyhmalnoho dyskursu ta ekonomichnoi komparatyvistyky. Rehionalna ekonomika, 1, 77-84. [In Ukrainian].

Kulchytskyi, Ya. V., Kulchytskyi, B. V., \& Dzhyhora, N. V. (2016). Institutional Bases of Interpretation of the Economic Systems in the Conditions of Strengthening of their Environmentally Sustainable Development and Globalization. Scientific Bulletin of UNFU, 26(6), 7-13. https://doi.org/10.15421/40260601

Kulchytskyi, Ya. V., Kulchytskyi, B. V., Bashnianyn, H. I., \& Osetskyi, V. L. (2017a). Filosofiia ekonomichnykh system u kon- teksti hnoseolohii suspilno-ekonomichnykh transformatsii. In $H$. $I$. Bashnianyn (Ed.), Ekonomichni systemy. (Vol. 6). Lviv: Liha-Pres, pp. 60-96. [In Ukrainian].

Kulchytskyi, Ya. V., Kulchytskyi, B. V., Bashnianyn, H. I., \& Osetskyi, V. L. (2017b). Instytutsiinyi pidkhid do traktuvannia ekonomichnykh system za umov posylennia yikh ekolohizatsii ta hlobalizatsii. In H. I. Bashnianyn, B. M. Shevchyk (Eds), Systemnyi analiz ekonomichnykh system: Zbirnyk naukovykh prats za materialamy Druhoho Vseukrainskoho kruhloho stolu (pp. 9-15). Lviv: Liha-Pres. [In Ukrainian].

Kulchytskyi, Ya. (2017). Formuvannia ekolohichnoi svidomosti ta kultury pid chas vykladannia ekonomichnykh dystsyplin. Ekolohizatsiia osvity yak chynnyk staloho rozvytku suspilstva: Materialy Mizhnarodnoi naukovo-praktychnoi konferentsii (pp. 68-71). Lviv: RVV NLTU Ukrainy. [In Ukrainian].

Kulchytskyi, Ya. V., Kulchytskyi, B. V., \& Malinovska, M. V. (2018). An Ecologization of the Economic Systems as Priority of Their Transformation in XXI Century. Scientific Bulletin of UNFU, 28(4), 15-19. https://doi.org/10.15421/40280402

Melnyk, L. H. (2006). Osnovy stiikoho rozvytku. Sumy: VTD "Universytetska knyha", 383 p. [In Ukrainian].

Tunytsia, Yu. Yu. (2006). Ekoekonomika i rynok: podolannia superechnostei. Kyiv: Znannia, 314 p. [In Ukrainian].

Fiedor, B. (Ed.), Czaja, S., Graczyk, A., \& Jakubczyk, Z. (2012). Podstawy ekonomii środowiska i zasobów naturalnych. Warszawa: Wydawnictwo C. H. Beck, 484 p.

Ya. V. Kul'chyts'kyj', B. V. Kul'chyts'kyj', L. V. Ribun'

${ }^{I}$ Ukrainian National Forestry University, Lviv, Ukraine

${ }^{2}$ Ivan Franko National University of Lviv, Lviv, Ukraine

\section{THE ECOLOGICAL PARADIGM OF THE COMPARATIVE ANALYSIS OF ECONOMIC SYSTEMS OF THE 21 CENTURY}

Intensifying of problem of mutual relations of man and environment stipulated a statement in the economic theory of ecological paradigm, which foresees consideration of all economic and social processes through the prism of environmental terms of existence and development of human personality preservation. It is marked that modern textbooks on economic theory underestimate an ecological imperative, because it is necessary to investigate people behaviour in the process of production, distribution and consumption of material welfare and services not only in the conditions of the limited resources, but already in new terms of intensifying of ecological crisis of global, regional and local character. Institutional principles of ecologization of the modern economic systems are exposed considering a post-industrial paradigm and comparisons of economic systems in the conditions of strengthening of globalization. The maintenance of ecological paradigm of economic theory is educed and the necessity of selection of social-and-ecological relations is reasonable for the system of economic relations of society. The conception is analysed of steady development and feature of ecological-economic instruments in the developed countries. The importance of forming of modern ecological culture is highlighted in the process of transformation of the economic systems, when orientation at ecological expediency and safety, absence of contrasting of man and nature should be in its basis. Authors' interpretation of the process of ecologization of the modern economic systems is offered in the conditions of strengthening of globalization, transition of humanity to society of knowledge and "green economy". We suggest understanding the ecologization of the economic systems as strengthening of ecological orientation of the economic systems in the process of their transformation, which means gaining of modern economic and ecological consciousness and culture, ecological responsibility, claim of modern ecological values, forming of corresponding normatively-legal, institutional base, sent to the public inspection after the system of connections "man is an economy - ecology", application of approvals and stimuli in relation to influence of the economic system on the state of ecological equilibrium in the conditions of the limited natural resources and intensifying of ecological crisis of global, regional and local character. The ecologization of the economic systems is the objective process of their transformation, by the dominant of transformation on the fracture of millenniums, which asserts realization of ecological problems as global. Today, the ecologization of the economic systems is examined as very important, even qualificatory criterion of comparative analysis of the national systems or international system educations. The ecological paradigm of the comparative analysis of the economic systems of the 21 century is reasonable.

Keywords: economic systems; ecologization of the economic systems; environment development; ecological paradigm of economic theory and comparative analysis of the economic systems of the 21 century. 